NASA/TM-2002-211713

\title{
Battery Reinitialization of the Photovoltaic Module of the International Space Station
}

Gyan Hajela and Fred Cohen

The Boeing Company, Canoga Park, California

Penni Dalton

Glenn Research Center, Cleveland, Ohio 
Since its founding, NASA has been dedicated to the advancement of aeronautics and space science. The NASA Scientific and Technical Information (STI) Program Office plays a key part in helping NASA maintain this important role.

The NASA STI Program Office is operated by Langley Research Center, the Lead Center for NASA's scientific and technical information. The NASA STI Program Office provides access to the NASA STI Database, the largest collection of aeronautical and space science STI in the world. The Program Office is also NASA's institutional mechanism for disseminating the results of its research and development activities. These results are published by NASA in the NASA STI Report Series, which includes the following report types:

- $\quad$ TECHNICAL PUBLICATION. Reports of completed research or a major significant phase of research that present the results of NASA programs and include extensive data or theoretical analysis. Includes compilations of significant scientific and technical data and information deemed to be of continuing reference value. NASA's counterpart of peerreviewed formal professional papers but has less stringent limitations on manuscript length and extent of graphic presentations.

- TECHNICAL MEMORANDUM. Scientific and technical findings that are preliminary or of specialized interest, e.g., quick release reports, working papers, and bibliographies that contain minimal annotation. Does not contain extensive analysis.

- CONTRACTOR REPORT. Scientific and technical findings by NASA-sponsored contractors and grantees.
- CONFERENCE PUBLICATION. Collected papers from scientific and technical conferences, symposia, seminars, or other meetings sponsored or cosponsored by NASA.

- SPECIAL PUBLICATION. Scientific, technical, or historical information from NASA programs, projects, and missions, often concerned with subjects having substantial public interest.

- TECHNICAL TRANSLATION. Englishlanguage translations of foreign scientific and technical material pertinent to NASA's mission.

Specialized services that complement the STI Program Office's diverse offerings include creating custom thesauri, building customized data bases, organizing and publishing research results ... even providing videos.

For more information about the NASA STI Program Office, see the following:

- Access the NASA STI Program Home Page at http://www.sti.nasa.gov

- E-mail your question via the Internet to help@sti.nasa.gov

- Fax your question to the NASA Access Help Desk at 301-621-0134

- Telephone the NASA Access Help Desk at 301-621-0390

- Write to:

NASA Access Help Desk

NASA Center for AeroSpace Information 7121 Standard Drive

Hanover, MD 21076 
NASA/TM-2002-211713

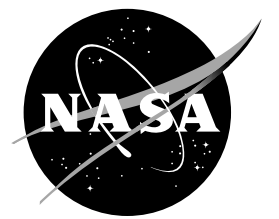

\section{Battery Reinitialization of the Photovoltaic Module of the International Space Station}

Gyan Hajela and Fred Cohen

The Boeing Company, Canoga Park, California

Penni Dalton

Glenn Research Center, Cleveland, Ohio

Prepared for the

37th Intersociety Energy Conversion Engineering Conference

sponsored by the Institute of Electrical and Electronics Engineers, Electron Devices Society

Washington, DC, July 28-August 2, 2002

National Aeronautics and

Space Administration

Glenn Research Center 


\section{Acknowledgments}

Authors are very thankful for the excellent coordination and assistance provided by the Boeing Houston Electric Power System, NASA Mission Evaluation Room, and NASA Mission Operations Directorate teams.

Available from

NASA Center for Aerospace Information 7121 Standard Drive

Hanover, MD 21076
National Technical Information Service 5285 Port Royal Road Springfield, VA 22100

Available electronically at http:/ /gltrs.grc.nasa.gov 
IECEC 200220033

\title{
BATTERY REINITIALIZATION ON THE PHOTOVOLTAIC MODULE OF THE INTERNATIONAL SPACE STATION
}

\author{
Gyan Hajela, Ph.D. and Fred Cohen \\ The Boeing Company, Rocketdyne Power \& Propulsion \\ 6633 Canoga Avenue \\ Canoga Park, CA 91309 \\ (818) 586-3251, Gyan.Hajela@Boeing.com \\ (818) 586-3206, Fred.Cohen@Boeing.com \\ Penni Dalton \\ NASA Glenn Research Center \\ 21000 Brookpark Road \\ Cleveland, OH 44135 \\ (216) 433-5223, Penni.J.Dalton@GRC.NASA.gov
}

\begin{abstract}
The photovoltaic (PV) module on the International Space Station (ISS) has been operating since November 2000 and supporting electric power demands of the ISS and its crew of three. The PV module contains photovoltaic arrays that convert solar energy to electrical power, and an integrated equipment assembly (IEA) that houses electrical hardware and batteries for electric power regulation and storage.

Each PV module contains two independent power channels for fault tolerance. Each power channel contains three batteries in parallel to meet its performance requirements and for fault tolerance. Each battery consists of $76 \mathrm{Ni}$-Hydrogen $\left(\mathrm{Ni}-\mathrm{H}_{2}\right)$ cells in series. These 76 cells are contained in two orbital replaceable units (ORU) that are connected in series.

On-orbit data are monitored and trended to ensure that all hardware is operating normally. Review of onorbit data showed that while five batteries are operating very well, one is showing signs of mismatched ORUs. The cell pressure in the two ORUs differs by an amount that exceeds the recommended range.

The reason for this abnormal behavior may be that the two ORUs have different use history. An assessment was performed and it was determined that capacity of this battery would be limited by the lower pressure ORU. Steps are being taken to reduce this pressure differential before battery capacity drops to the point of affecting its ability to meet performance requirements. As a first step, a battery reinitialization procedure was developed to reduce this pressure differential. The procedure was successfully carried out on-orbit and the pressure differential was reduced to the recommended range.
\end{abstract}

This paper describes the battery performance and the consequences of mismatched ORUs that make a battery. The paper also describes the reinitialization procedure, how it was performed on orbit and battery performance after the re-initialization.

On-orbit data monitoring and trending is an ongoing activity and it will continue as ISS assembly progresses.

\section{BATTERY ON-ORBIT DATA ASSESSMENT}

ISS batteries consist of $76 \mathrm{Ni}-\mathrm{H}_{2}$ cells connected in series. These 76 cells are installed in two ORUs connected in series to form a battery. Each battery is charged and discharged by a battery charge/discharge unit (BCDU). Each battery is connected to the primary power bus via a BCDU. Each power channel contains three BCDUs connected in parallel.

Battery on-orbit performance is monitored routinely and presented to ISS teams every 3 months. Based on the information to date, 5 out of 6 batteries are performing to the expectations. The following recommended parameters are used to assess battery health:

- $\quad$ Temperature difference between any two cells, out of 76 cells that make a battery, should be less than $3^{\circ} \mathrm{C}$. Batteries are actively cooled by circulating coolant through the coldplates over which the battery ORUs are mounted.

- Voltage difference between any two cells, out of 76 cells that make a battery, should be less than $0.05 \mathrm{~V}$.

- Voltage difference between the two ORUs that make a battery should be less than $2 \mathrm{~V}$.

- Pressure difference between the two ORUs, that make a battery, should be less than 100 psi.

All batteries operate within the limits outlined above except for the pressure difference of the ORUs within 
the battery $4 \mathrm{~B} 2$. Battery $4 \mathrm{~B} 2$ is showing a larger than expected pressure difference and the pressure difference is rising with time, Figure 1. However, the remaining parameters of this battery remain well within the ranges specified above-intercell temperature gradient $\sim 1.5^{\circ} \mathrm{C}$, intercell voltage gradient $\sim 0.03 \mathrm{~V}$, ORU voltage difference $\sim 0.5 \mathrm{~V}$.

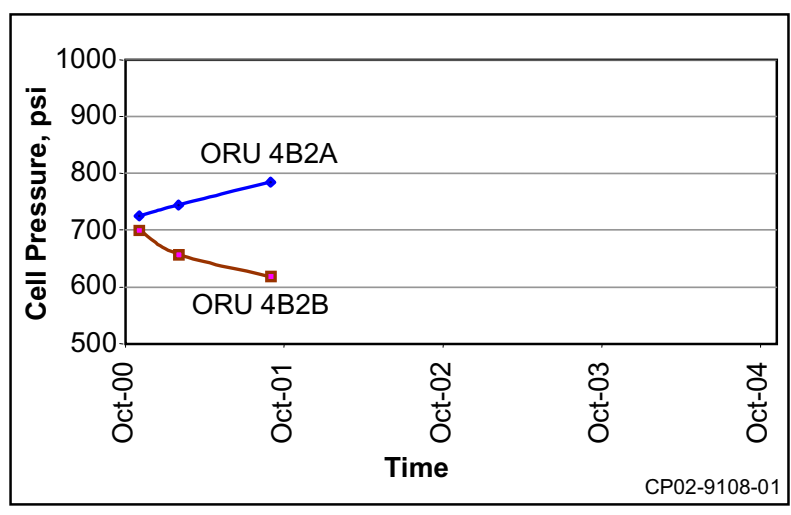

FIGURE 1. BATTERY 4B2 ORU PRESSURES

The 4B2 Battery is comprised of two ORUs that have cycle history differences or ages. This age difference was caused by 2 years of on-ground IEA testing. When the power channels were populated, the battery ORUs were matched to another containing cells of the same vintage (activation dates) but battery 4B2 contains two ORUs that have different ground test histories. We continue to monitor this battery very closely.

\section{IMPACTS OF BATTERY ORU PRESSURE DIFFERENTIAL}

Battery pressure is used by the control software to compute battery state of charge (SOC). The pressure used for the battery SOC calculation is the average of the two ORU pressures. Battery charge control algorithm computes charge current on the basis of the SOC. For battery 4B2, the SOC is based on the average between two widely different ORU pressures. Thus, the charge control algorithm attempts to bring the average SOC to $100 \%$ and this results in the ORU 4B2B operating at a lower SOC and the ORU 4B2A operating at a higher SOC. There are several impacts of this anomaly:

- Consequence of this pressure imbalance is that the ORU 4B2A is being overcharged. This results in higher heat generation and higher SOC. This ORU is being overstressed and this may reduce its life. Current battery models do not provide means to quantify this impact.

- $\quad$ The lower pressure and SOC ORU, 4B2B, is now the battery capacity controlling ORU. As the battery is discharged, this ORU will reach the limiting SOC and voltage before the other ORU and may cause the BCDU to trip because of low battery or low cell voltage.

\section{REINITIALIZATION PROCEDURE}

To resolve this performance anomaly, it was proposed to perform a controlled discharge of both batteries to a state of full discharge and then to charge them back up. This procedure would bring both ORUs to the same state before charging. This reinitialization is expected to reduce ORU pressure differential.

The following steps were proposed to perform reinitialization:

- Start with a fully charged battery 4B2 (SOC $>100 \%$ ).

- Maintain normal operation of the active thermal control to ensure that all batteries remain within their normal operating temperature range.

- Discharge 4B2 during eclipse period, in successive orbits, through channels loads. Inhibit charge during insolation periods.

- $\quad$ Continue this step until either one ORU voltage drops below $38 \mathrm{~V}$ or any cell voltage drops below $0.7 \pm 0.5 \mathrm{Vdc}$.

- $\quad$ This step is estimated to require 6 to 10 orbits depending on channel loads

- Open BCDU fault isolator (FI) and command BCDU 4B2 to standby mode

- $\quad$ Battery 4B2 is now isolated from the primary bus

- $\quad$ Channel 4B loads will be supported by BCDU $4 \mathrm{~B} 1$ and $4 \mathrm{~B} 3$

- Engage drain resistor in battery ORUs 4B2A and 4B2B to fully discharge both ORUs

- Continue discharge of each ORU, through dead-face resistor until voltage of one cell in that ORU drops below $0.1 \pm 0.3 \mathrm{Vdc}$.

- Disengage drain resistor. Continue this step until drain resistors in both ORUs are disengaged.

- Recharge battery 4B2 using normal start-up procedures

- Inhibit discharge until battery is fully charged (SOC > = 100\%)

- $\quad$ Resume normal operations with battery 4B2.

\section{ON-ORBIT EXECUTION}

Detailed procedures were prepared based on the steps listed above and the procedures were coordinated with all the involved ISS teams. The detailed procedures were tested in the Space Power Electronics Laboratory (SPEL) at the Boeing Canoga Park facility.

The whole procedure was estimated to require 2 to 3 days. It was planned to download supplemental data from orbit during these procedures to enable detailed analyses. This will enable fine-tuning of the procedures, if needed, while the reinitialization is in progress. The Mission Evaluation Room console staffing was increased to enable full time monitoring during reinitialization. 
Although BCDUs and batteries are designed such that two BCDUs can maintain channel loads, the loads were reduced to preserve fault tolerance. Reinitialization was scheduled for a period when orbit beta angles were high that resulted in reduced loads for the power channel 4B2.

Potential risks during re-initialization were assessed and found to be low. No special operational provisions were required.

Safety assessments were performed and it was concluded that reinitialization does not cause any safety risks to the ISS or crew.

Test delay and termination criteria were established and coordinated with all involved teams.

Reinitialization was successfully performed on battery 4B2 during the last week of February 2002. All procedures were executed as planned.

- All batteries were fully charged at the start of the procedure, GMT 057/14:50, and the 4B2 pressure differential was observed to be 170 psi (GMT 057 corresponds to Feb. 26).

- Channel loads (4.4 kW shared by three BCDUs) were used to discharge battery during eclipse periods and charge was inhibited during the insolation periods. As expected, ORU 4B2B (lower pressure ORU) reached the cutoff cell voltage of $0.7 \mathrm{~V}$ first, at GMT 058/08:15

- It took a little longer ( $\sim 11$ orbits) than initially estimated (6 to 10 orbits) because the eclipse periods were shorter (high orbit beta angle) and channel loads were low.

- Figure 2 shows the battery cell temperature during this step. All cells remain well within the allowable temperature limits of 32 to $50^{\circ} \mathrm{F}$, and the temperature difference between cells remained within a design-to range of $5.4^{\circ} \mathrm{F}$.

- $\quad$ Figure 3 shows cell voltages. It shows that the cell \#08 of ORU 4B2B reached the cutoff voltage first.

- $\quad$ Figure 4 shows ORU voltages and the battery voltage (sum of the voltages of the two ORUs connected in series). It shows that the battery voltage remained well above the cutoff value of $76 \mathrm{~V}$.

- $\quad$ Figure 5 shows cell pressures. It can be seen that cells of ORU 4B2A and 4B2B remained tightly grouped together. Cell pressures dropped steadily during the eclipse periods and stayed unchanged during the insolation periods (charge inhibited). Average pressure of ORU $4 B 2 A$ and $4 B 2 B$ remained apart by about the same value during the discharge.

- $\quad$ Figure 6 shows the battery capacity. It shows that the battery capacity was 51.6 A.hr at this rate of discharge $\left(\begin{array}{lll}\sim 17 & \text { A. }) \text {. Note that the }\end{array}\right.$ batteries need to discharge $50 \mathrm{~A}$.hr to satisfy all discharge power requirements (continuous and contingency) and, thus, it is shown that the batteries continued to meet or exceed all power performance requirements even before reinitialization.
- After one cell reached the threshold voltage of $0.7 \mathrm{~V}$, battery 4B2 was open circuited and isolated from the BCDU and drain resistors were engaged in both ORUs, at GMT 059/01:58.

- ORU 4B2B was fully discharged, one cell below $0.1 \mathrm{~V}$, at GMT 059/05:46. Figures 2 through 6 show how various monitored parameters changed during this step.

- Figure 2 shows that all cells remained well within the allowable temperature limits of 32 to $50^{\circ} \mathrm{F}$. Note that the temperature difference between cells remained within a design-to range of $5.4^{\circ} \mathrm{F}$.

- Figure 3 shows that it was again the cell \#08, of ORU 4B2B, which reached the cutoff voltage of $0.1 \mathrm{~V}$ first.

- Note that cells in the ORU 4B2A has still not reached the first cutoff level, cell voltage below $0.7 \mathrm{~V}$. This clearly shows the inequality of stored capacity between the two ORUs.

- Also note that the ORU 4B2B, cell \#08 voltage rose to about $1.2 \mathrm{~V}$ when it was disconnected from the load (after dropping to below $0.7 \mathrm{~V}$ ). Similar trend was demonstrated after this cell reached the second cutoff voltage of $0.1 \mathrm{~V}$ while on the drain resistor. The voltage rose again, to about $0.3 \mathrm{~V}$, as soon as the drain resistor was disengaged.

- Figure 4 shows that the battery voltage remained well above the cutoff value of $76 \mathrm{~V}$.

- $\quad$ Figure 5 shows that cells of ORU 4B2A and 4B2B remained tightly grouped together, as before. Average pressure of ORU 4B2A and 4B2B remained apart by about the same value during this step, that is, no change in the ORU pressure differential.

- After one cell in ORU 4B2B reached the cutoff voltage of $0.1 \mathrm{~V}$, drain resistor for that ORU was disengaged. Drain resistor for the ORU 4B2A remained engaged.

- Cell \#04 of ORU 4B2A reached its cutoff voltage threshold of $0.1 \mathrm{~V}$ at GMT 059/21:30. Figures 2 through 6 show how various monitored parameters changed during this step.

- Figure 2 shows that all cells remained well within the allowable temperature ranges.

- Figure 3 shows that it was cell \#04 of ORU 4B2A that dropped first. Due to loss of communications with the ISS, the data showing drop to $0.1 \mathrm{~V}$ were lost.

- Figure 5 shows that cells of ORU 4B2A and 4B2B remained tightly grouped together, as before. Pressure of cells in ORU 4B2A dropped during this step while pressure of cells in ORU 4B2B stayed the same. ORU pressure differential, at the time when ORU 4B2A reached the cell cutoff voltage, was reduced to 50 psi. 


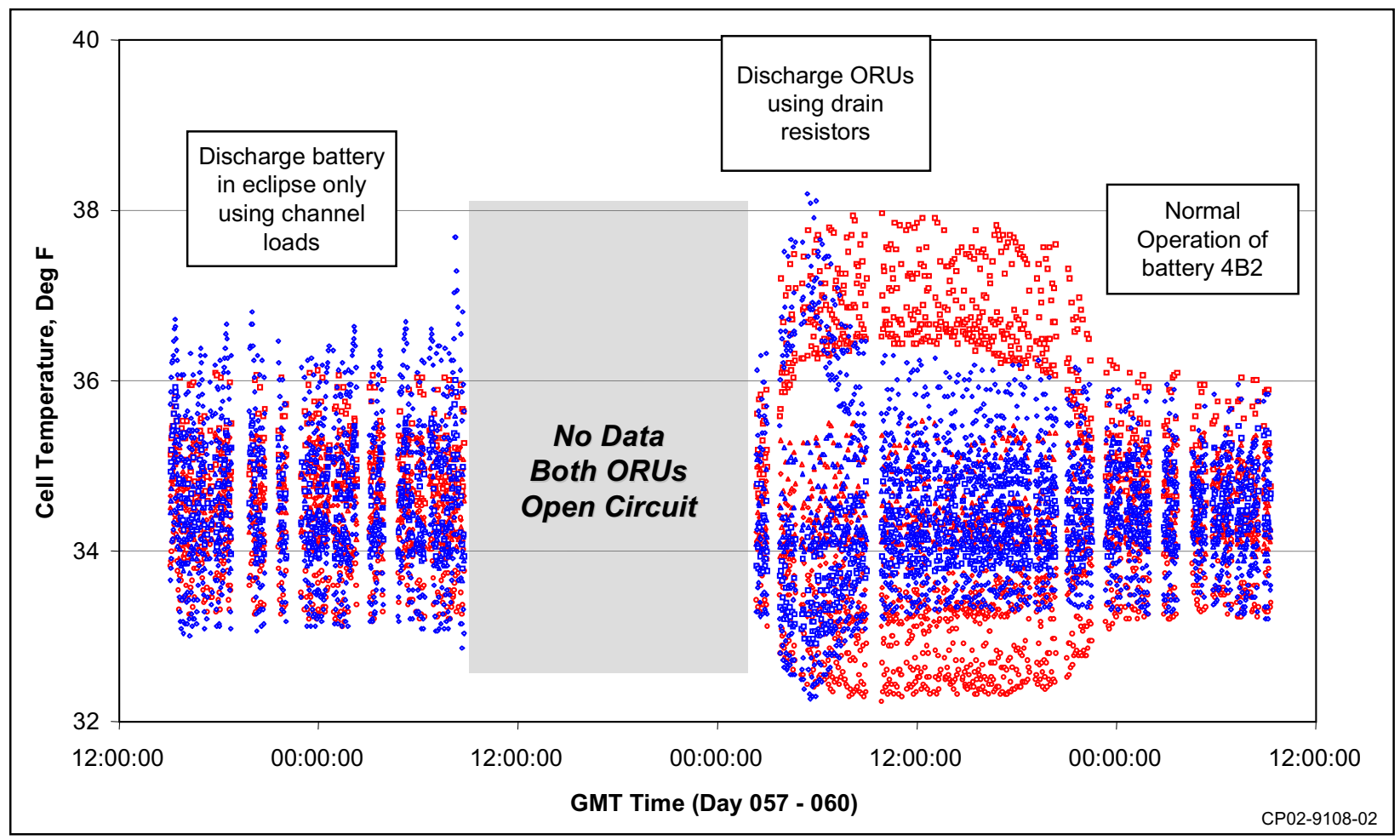

FIGURE 2. MONITORED BATTERY CELL TEMPERATURES

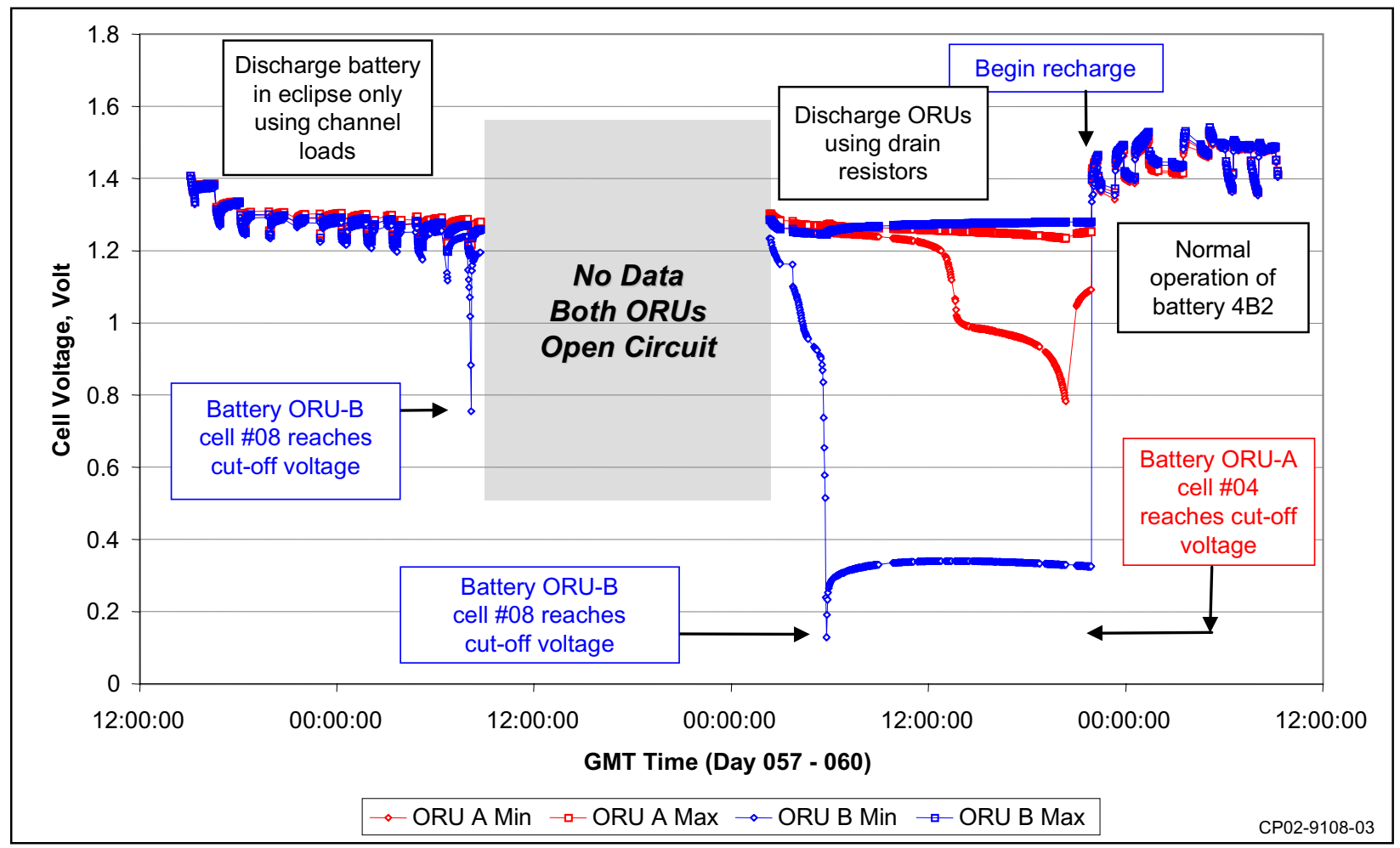

FIGURE 3. BATTERY CELL VOLTAGES, MIN AND MAX 


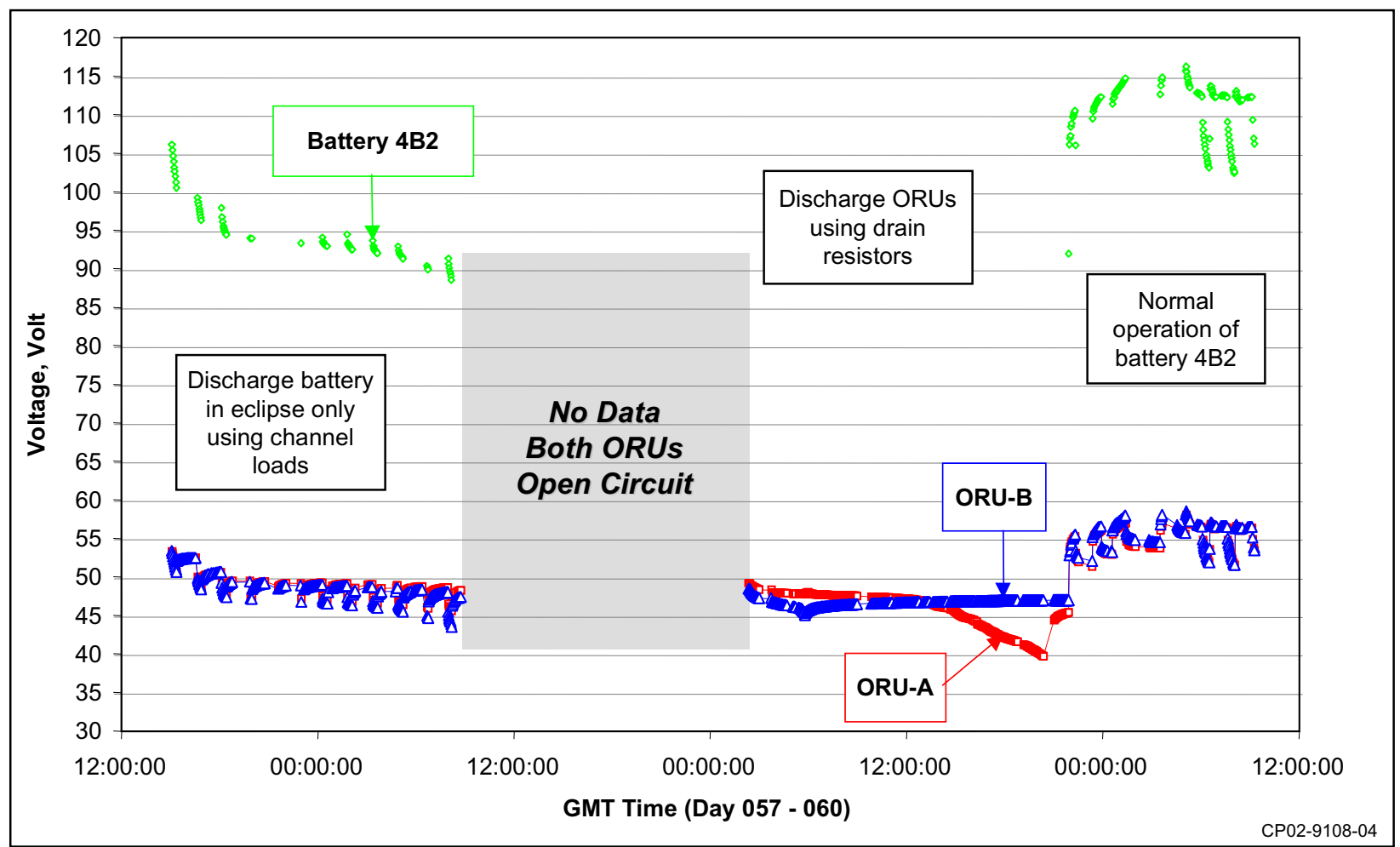

FIGURE 4. 4B2 VOLTAGES VS. TIME

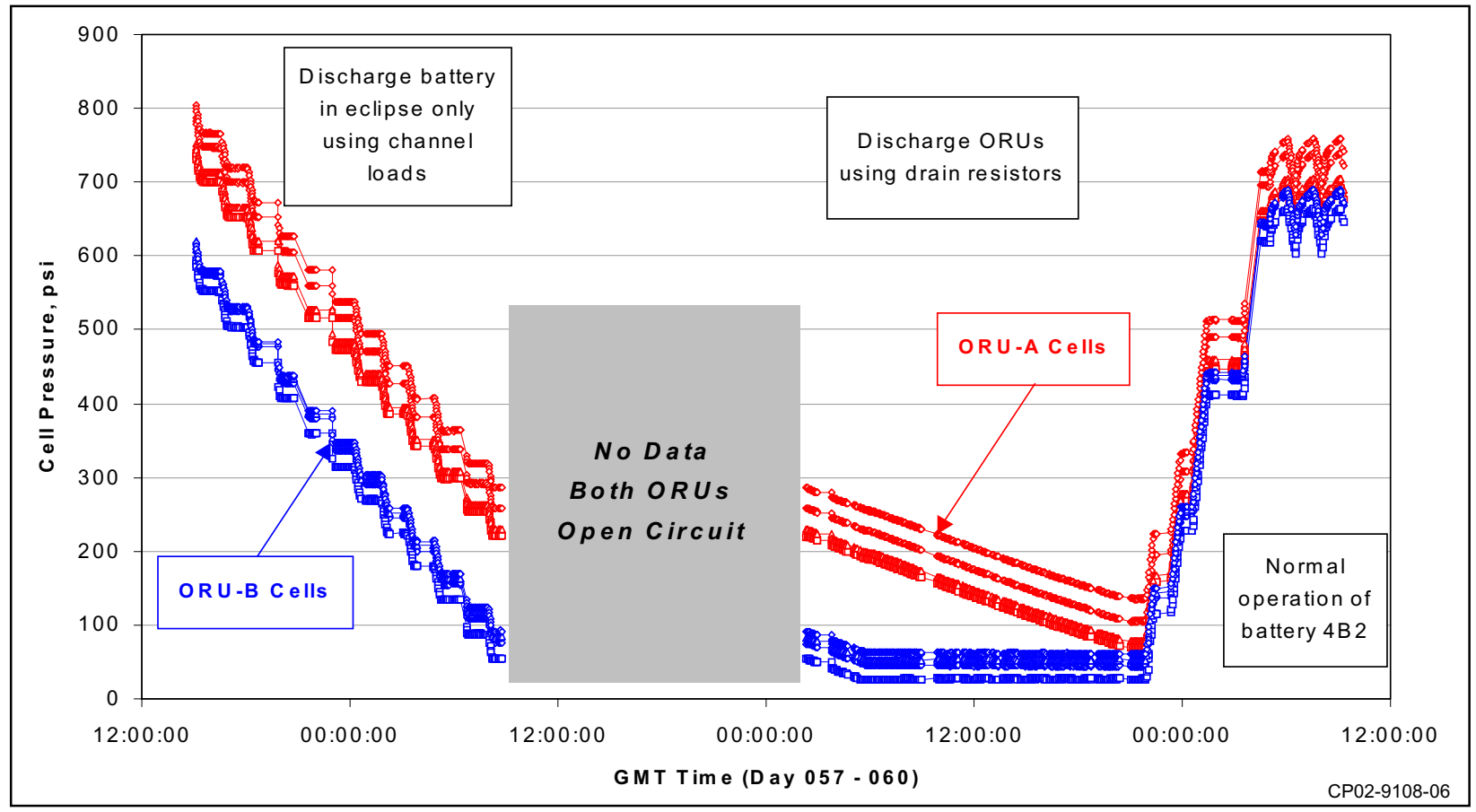

FIGURE 5. MONITORED CELL PRESSURES 


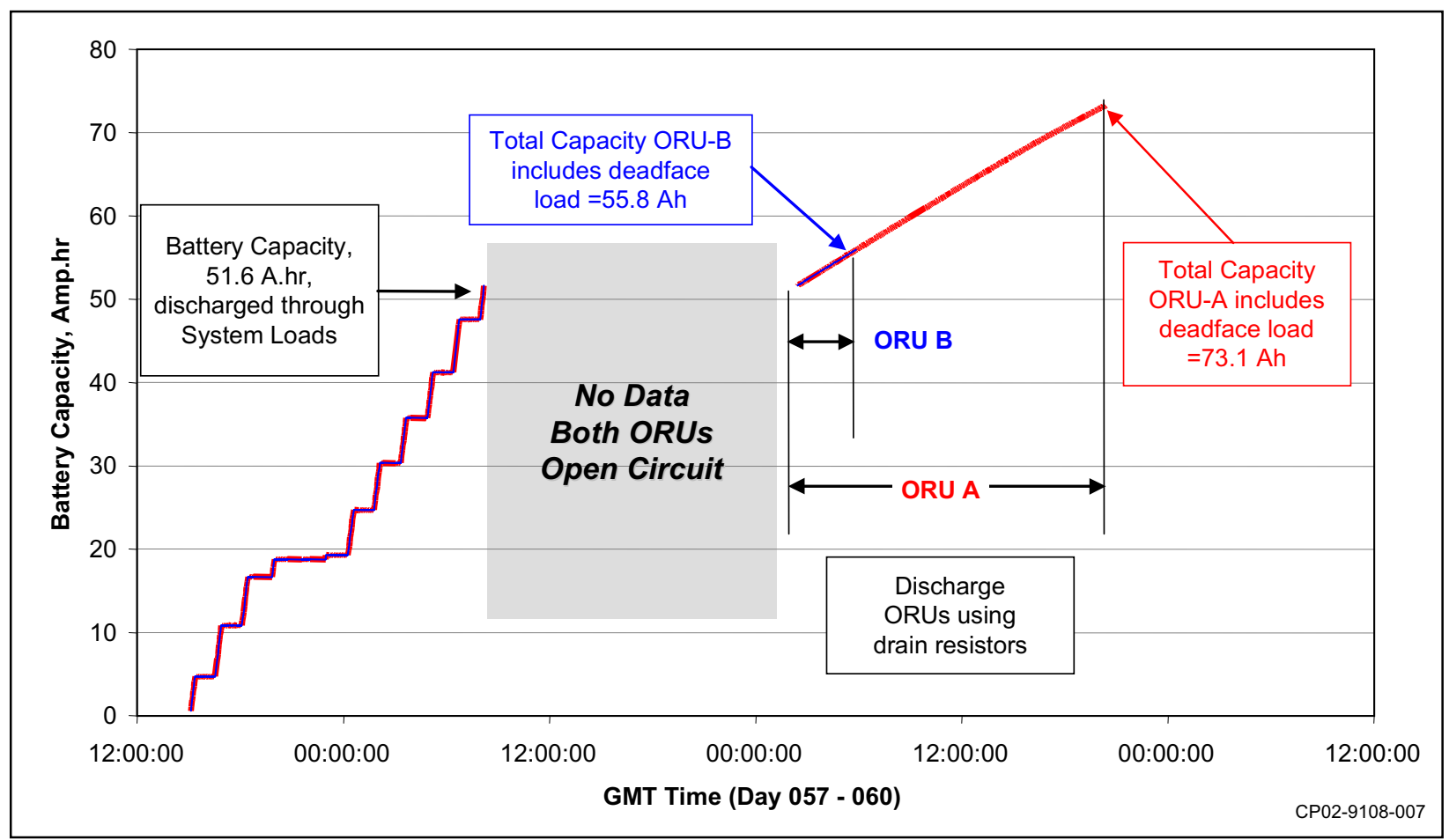

FIGURE 6. CALCULATED CAPACITY

- $\quad$ After one cell in ORU 4B2A reached the cutoff voltage of $0.1 \mathrm{~V}$, drain resistor for that ORU was also disengaged.

- Battery 4B2 was charged during insolation periods only at the nominal charge rate of $30 \mathrm{~A}$. Battery 4B2 was isolated from the primary bus during the eclipse periods. Again Figures 2 through 6 show how various monitored parameters trended during this step.

- $\quad$ Battery was fully charged at GMT 060/05:59 and was returned to normal duty.

- Battery reinitialization reduced the pressure differential between the two ORUs to $42 \mathrm{psi}$ from the 170 psi level at the start of the reinitialization procedures.

- Boeing Electric Power System team continues to monitor on-orbit battery performance. Recent data has shown that battery $4 \mathrm{~B} 2$ differential pressure is growing again. The trend is being analyzed and additional corrective actions are being planned.

\section{SUMMARY AND CONCLUSIONS}

The procedures were carried out as planned. The successful execution of reinitialization is attributable to the preplanning and coordination work during the preparation phase. No hitches were encountered during the execution because the procedures were thoroughly tested in SPEL before their use on orbit.

The data showed that battery capacity was compromised because of pressure differential between the two ORUs. Data also showed that battery continued to satisfy its performance requirements-only the capacity margin was lost.

The data show that the reinitialization was successful in reducing the ORU pressure differential. This reduction, however, was only temporary. Additional corrective measures are being planned for future implementation. Battery monitoring is continuing. 
Public reporting burden for this collection of information is estimated to average 1 hour per response, including the time for reviewing instructions, searching existing data sources, gathering and maintaining the data needed, and completing and reviewing the collection of information. Send comments regarding this burden estimate or any other aspect of this collection of information, including suggestions for reducing this burden, to Washington Headquarters Services, Directorate for Information Operations and Reports, 1215 Jefferson Davis Highway, Suite 1204, Arlington, VA 22202-4302, and to the Office of Management and Budget, Paperwork Reduction Project (0704-0188), Washington, DC 20503.

\begin{tabular}{|l|c|r|}
\hline 1. AGENCY USE ONLY (Leave blank) & $\begin{array}{c}\text { 2. REPORT DATE } \\
\text { July } 2002\end{array}$ & $\begin{array}{r}\text { 3. REPORT TYPE AND DATES COVERED } \\
\text { Technical Memoran }\end{array}$
\end{tabular}

4. TITLE AND SUBTITLE

5. FUNDING NUMBERS

Battery Reinitialization of the Photovoltaic Module of the

International Space Station

6. AUTHOR(S)

Gyan Hajela, Fred Cohen, and Penni Dalton

WU-478-29-10-00

National Aeronautics and Space Administration

John H. Glenn Research Center at Lewis Field

Cleveland, Ohio 44135-3191

8. PERFORMING ORGANIZATION

REPORT NUMBER

E-13464

9. SPONSORING/MONITORING AGENCY NAME(S) AND ADDRESS(ES)

10. SPONSORING/MONITORING

National Aeronautics and Space Administration

Washington, DC 20546-0001

AGENCY REPORT NUMBER

NASA TM-2002-211713

IECEC-2002-20033

\section{SUPPLEMENTARY NOTES}

Prepared for the 37th Intersociety Energy Conversion Engineering Conference sponsored by the Institute of Electrical and Electronics Engineers, Electron Devices Society, Washington, DC, July 28-August 2, 2002. Gyan Hajela and Fred Cohen, The Boeing Company, Canoga Park, California 91309; Penni Dalton, NASA Glenn Research Center. Responsible person, Penni Dalton, organization code 6910, 216-433-5223.

12a. DISTRIBUTION/AVAILABILITY STATEMENT

12b. DISTRIBUTION CODE

Unclassified - Unlimited

Subject Category: 20

Distribution: Nonstandard

Available electronically at http://gltrs.grc.nasa.gov

This publication is available from the NASA Center for AeroSpace Information, 301-621-0390.

13. ABSTRACT (Maximum 200 words)

The photovoltaic (PV) module on the International Space Station (ISS) has been operating since November 2000 and supporting electric power demands of the ISS and its crew of three. The PV module contains photovoltaic arrays that convert solar energy to electrical power and an integrated equipment assembly (IEA) that houses electrical hardware and batteries for electric power regulation and storage. Each PV module contains two independent power channels for fault tolerance. Each power channel contains three batteries in parallel to meet its performance requirements and for fault tolerance. Each battery consists of $76 \mathrm{Ni}-\mathrm{Hydrogen}\left(\mathrm{Ni}-\mathrm{H}_{2}\right)$ cells in series. These 76 cells are contained in two orbital replaceable units $(\mathrm{ORU})$ that are connected in series. On-orbit data are monitored and trended to ensure that all hardware is operating normally. Review of on-orbit data showed that while five batteries are operating very well, one is showing signs of mismatched ORUs. The cell pressure in the two ORUs differs by an amount that exceeds the recommended range. The reason for this abnormal behavior may be that the two ORUs have different use history. An assessment was performed and it was determined that capacity of this battery would be limited by the lower pressure ORU. Steps are being taken to reduce this pressure differential before battery capacity drops to the point of affecting its ability to meet performance requirements. As a first step, a battery reinitialization procedure was developed to reduce this pressure differential. The procedure was successfully carried out on-orbit and the pressure differential was reduced to the recommended range. This paper describes the battery performance and the consequences of mismatched ORUs that make a battery. The paper also describes the reinitialization procedure, how it was performed on orbit, and battery performance after the reinitialization. On-orbit data monitoring and trending is an ongoing activity and it will continue as ISS assembly progresses.

14. SUBJECT TERMS

Battery; Nickel-hydrogen; ISS power
15. NUMBER OF PAGES

12

16. PRICE CODE

\begin{tabular}{|c|c|c|}
\hline $\begin{array}{c}\text { 17. SECURITY CLASSIFICATION } \\
\text { OF REPORT } \\
\text { Unclassified }\end{array}$ & $\begin{array}{c}\text { 18. SECURITY CLASSIFICATION } \\
\text { OF THIS PAGE } \\
\text { Unclassified }\end{array}$ & $\begin{array}{c}\text { 19. SECURITY CLASSIFICATION } \\
\text { OF ABSTRACT } \\
\text { Unclassified }\end{array}$ \\
\hline
\end{tabular}

NSN 7540-01-280-5500

Standard Form 298 (Rev. 2-89)

Prescribed by ANSI Std. Z39-18 298-102 